Journal of Engineering and Applied Sciences 14 (Special Issue 5): 8929-8932, 2019

ISSN: 1816-949X

(C) Medwell Journals, 2019

\title{
Response of Esherichia coli to the Alcoholic Extract of Green Alga Chlorococcum humicola
}

\author{
${ }^{1}$ Raad Abdul Hadi Nayyef and ${ }^{2}$ Thaer Mohammed Ibrahim \\ ${ }^{1}$ Department of Biology, Open Educational College, Ministry of Educational, Iraq \\ ${ }^{2}$ Department of Biology, College of Pure Sciences, University of Baghdad-Ibn Al-Haytham, Iraq
}

\begin{abstract}
The response of Escherichia coli bacteria witch was isolated from contaminated water to Chlorococcum humicola alcoholic algae extract was studied on growth and different parameters. The Extract concentration of C. humicola wear $0.07,0.15,0.31,0.2$ and $1.25 \mathrm{mg} \mathrm{L}^{-1}$. showed a high efficiency in significant reducing numbers of $E$. coli, the Growth Account (GA) showed a highest value at concentration $0.07 \mathrm{mg} \mathrm{L}^{-1}$ which was 303,200 and $168 \mathrm{CFU} \mathrm{mL}^{-1}$ and less value at. $1.25 \mathrm{mg} \mathrm{L}^{-1}$ which was 99,61 and $49 \mathrm{CFU} \mathrm{mL}^{-1}$ in 24,48 and $72 \mathrm{~h}$, respectively. While removal account (RA) appeared highest value at $1.25 \mathrm{mg} \mathrm{L}^{-1}, 333,419$ and $431 \mathrm{CFU} \mathrm{mL}^{-1}$ and less value at concentration $0.07 \mathrm{mg} \mathrm{L}^{-1}$ which was 150 and $27.312 \mathrm{CFU} \mathrm{mL} \mathrm{m}^{-1}$. Also the mortality percent (MP) appeared highest value at $1.25 \mathrm{mg} \mathrm{L}^{-1}$ $\left(68,87\right.$ and $89 \mathrm{CFU} \mathrm{mL}^{-1}$ ) and less value at $0.07 \mathrm{mg} \mathrm{L}^{-1}$ witch was 31,58 and $65 \mathrm{CFU} \mathrm{mL}^{-1}$ as well as the removing percentage of $E$. coli by green algae $C$. humicola which was 60,80 and $82 \%$ in 24,48 and $72 \mathrm{~h}$, respectively. The result of study improved that the species $E$. coli is high sensitive to $C$. humicola alga extracts toxicity of algal extracts were time and concentration dependent. The aim of the study refers to can be used as biodegradation agent in order to disposal of pollution by $E$. coli witch represent the bacterial water pollutant, with possibility to used the alcoholic extract of green alga to reducing the time and cost the water treatment.
\end{abstract}

Keywords: Alcoholic algae extract, toxicity, polluted water

\section{INTRODUCTION}

Water Sources, especially surface water, is exposed to the dangers of pollution, which leads, directly or indirectly, to the ecosystem. Water pollution means any change in the physical, chemical and biological characteristics of water, as well as the pathogens resulting from the effects of microorganisms such as bacteria, fungi and viruses (Cervenka et al., 2006).

The rivers are the most water bodies susceptible to pollution because of the discharges resulting from the various human activities that make them unusable only after the adoption of additional treatment and liquidation units of high and cost technology.

The presence of $E$. coli and other faucal indicator organisms such as Streptococci in surface waters can indicate a human health hazard because faecal contamination increases the risk of euteric pathogenic microorganisms being endemic transport of FIOs from land to bathing water (SEPA., 2002) and to river water abstracted for irrigation of ready to eat vegetables (Beuchat, 1996) are there for of public concern, the regulation of such contamination is covered in European union by directives such as the bathing waters directive and more recently the water framework directive (EU, 2000).
The $E$. coli was associated with watery or bloody diarrhea hemorrhagic colitis and hemolytic uremic syndrome (Stephan and Untermann, 1999). The organisms typically colonizes the infant gastrointestinal tract within hours of life there after $E$. coli and the host derive mutual benefit. The organisms is distributed in the environment as well as in the bowel of human and animals. It is also present in water supplies as an indicator of resent fecal contamination and potential presence of enteric pathogens (Collee et al., 1996).

Algae are mainly aquatic simple plants found in marine and fresh water as well as terrestrial habitats such as wet rocks or moist soils (NCERT., 2008) microalgae can be a rich source of mane chemically diverse.

Compounds that having used as a bioactive compounds as antimicrobial agents (Stengel and Connan, 2015). making the research use it in human pathology and also in aquaculture as biodegradation which is one of the most effective methods to remediating environmental systems in both situremid and engineered schemes, to reduce costs and environmentally-friendly than traditional detoxifying methods in contaminated environments (Mahmoudi, 2013).

In addition to the use of chemical sterilizers. The algae are microorganisms that are highly efficient in inhibiting the growth and effectiveness of various microorganisms (Katırcığlu et al., 2004).

Corresponding Author: Raad Abdul Hadi Nayyef, Department of Biology, Open Educational College, Ministry of Educational, Iraq 
It also contributes to the process of self-purification in the water bodies through the photosynthesis process, where they releases the dissolved oxygen gas, which causes the gas balance between oxygen and carbon dioxide between the atmosphere and water, that have a biological, medical and economic importance and are necessary to sustain life (Likens, 2010).

As well as algae have recently received a lot of attention as a new biomass source for the production of a new energy (Zhao et al., 2008). Some of the main characteristics which set algae apart from other biomass sources are that algae can have a high oil or starch content do not require agricultural land. Fresh water is not essential and nutrients that can be supplied by waste water and $\mathrm{CO}_{2}$ by combustion gas (Marina et al., 2013). The first distinction that needs to be made is between macro algae or versus microalgae (Xu et al., 2004).

Therefore, the aim of the study was to eliminate Escherichia coli, using the Alcoholic algae extract.

\section{MATERIAL AND METHODS}

Isolation and diagnosis of bacterial: The bacteria Escherichia coli, were isolated from the drainage water of the Rustmiya Sewage Treatment Plant in Baghdad using Prescott method (Kumar et al., 2010) grown on the Nutrient agar medium, then (Cervenka et al., 2006) $1 \mathrm{~mL}$ were taken from pure isolation into glass vials containing broth nutrient medium and incubated at $37^{\circ} \mathrm{C}$.

Preparation of dried algae: Chlorococcum humicola was isolated from small stream near the University of Baghdad-Jadriya, from different places where several samples were collected, depends on method of Stein (1973).

Then the alga was laboratory diagnosed using a microscope based on the diagnosis method (APHA., 2005).

The alga was cultured under constant laboratory conditions and temperature of $25 \pm 2^{\circ} \mathrm{C}, 3000$ lux and 16:8 light:dark as photo system in Chu 13 media (Yamaguchi et al., 1987) (incubated in the incubation room for 18 days, harvested by Centrifuge with of $3000 \mathrm{rpm}$ speed for $15 \mathrm{~min}$, the sedimentation dried in oven at $50^{\circ} \mathrm{C}$ for $48 \mathrm{~h}$, all samples keeps in $25^{\circ} \mathrm{C}$ antal used (Jawad, 1982; Eppley et al., 1977).

Extraction of active substances from algae: About $15 \mathrm{~g}$ of the dried algae was dissolved in $250 \mathrm{~mL}$ of Chloroform and then placed in shaking incubator at $25^{\circ} \mathrm{C}$ with $170 \mathrm{rpm}$ for $15 \mathrm{~min}$ and then dried at $40^{\circ} \mathrm{C}$ (Taskin et al., 2007).
Preparation of concentrations of algae extract: Cervenka et al., (2006) $1 \mathrm{~mL}$ of bacterial suspension was taken for each isolation of bacterial isolates and placed in a sterile glass flask containing different concentrations of the extract: $0.07,0.15,0.31,0.62$ and $1.25 \mathrm{mg} \mathrm{L}^{-1}$ prepared from the primary concentration by the dilutions and then the volume was completed to $100 \mathrm{~mL}$ of sterile sewage water with SEPA. (2002) repeated of each bacterial isolation. In addition to the control treatment which was free of the algae extract and incubated at $37^{\circ} \mathrm{C}$ for $72 \mathrm{~h}$ (Kumar et al., 2010).

The number of bacterial cells was calculated in Cervenka et al. (2006) $\mathrm{mL}$ of bacterial suspension using the method of Hemocytometer (Chamber counting) where the calculation was daily for three days to draw growth carve and account the growth account (GA), removal account (RA), mortality percent (MP) and removing percentage (RP) according to Dahiru and Obidoa (2007).

\section{RESULTS AND DISCUSSION}

The result showed exposure of $E$. coli bacteria to different concentrations of $C$. humicola alcoholic extract clearly effect on the growth curve decreed depends on these cells within $72 \mathrm{~h}$. From exposure a decrease was observed within increased emphasis and register a growth curve rapprochement and non-significant differences of the cells number at concentrations $0.13,0.62$ and $1.25 \mathrm{mg} \mathrm{L}^{-1}$ in $48 \mathrm{~h}$ (Fig. 1). while growth account (GA) showed a clear decline as significant for all concentrations compared with control witch was not exposed to algae extract witch registered $(168,200$ and 303) and 133, 177 and $303 \mathrm{CFU} \mathrm{mL}^{-1}$ in concentration of $0.07 \mathrm{mg} \mathrm{L}^{-1}$ and 100,100 and $248 \mathrm{CFU} \mathrm{mL} \mathrm{m}^{-1}$ by concentration of $0.15 \mathrm{mg} \mathrm{L}^{-1}$ and 100,100 and $248 \mathrm{CFU} \mathrm{mL}^{-1}$ by concentration of $0.31 \mathrm{mg} \mathrm{L}^{-1}$ while registered the two concentration 1.25 and $0.62 \mathrm{mg} \mathrm{L}^{-1}$ value reached (61, 72 and 180) and (49,61 and 99) after 24, 48 and $72 \mathrm{~h}$, respectively while the control which was register $480 \mathrm{CFU} \mathrm{mL}^{-1}$ after same period (Table 1).

Also register the removal account (RA) a value with significant and increased his concentration and the value converged with non-significant after 24,48 and $72 \mathrm{~h}$. Between 1.25 and $0.62 \mathrm{mg} \mathrm{L}^{-1}$ and the signification between the high concentration compared with the less two concentration which used at the study witch all the values significant compared with control (Table 2).

As well as mortality percent (MP) register values reached 31,58 and $65 \%$ at concentration $0.07 \mathrm{mg} \mathrm{L}^{-1}$, 37,63 and $71 \%$ at $0.15 \mathrm{mg} \mathrm{L}^{-1}$ and 47,74 and $79 \%$ at $0.31 \mathrm{mg} \mathrm{L}^{-1} 62,85$ and $87 \%$ at concentration $0.62 \mathrm{mg} \mathrm{L}^{-1}$ after 24,48 and $72 \mathrm{~h}$, respectively (Table 3 ). 


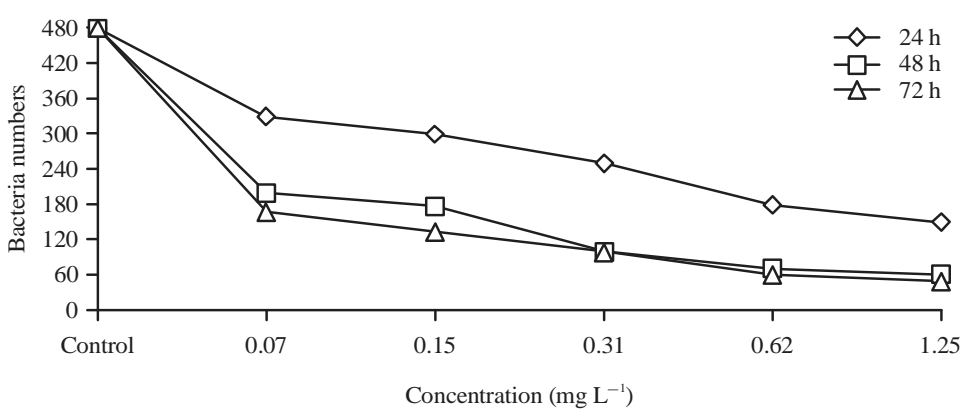

Fig. 1: Decreasing of $E$. coli numbers using algae extract during $72 \mathrm{~h}$

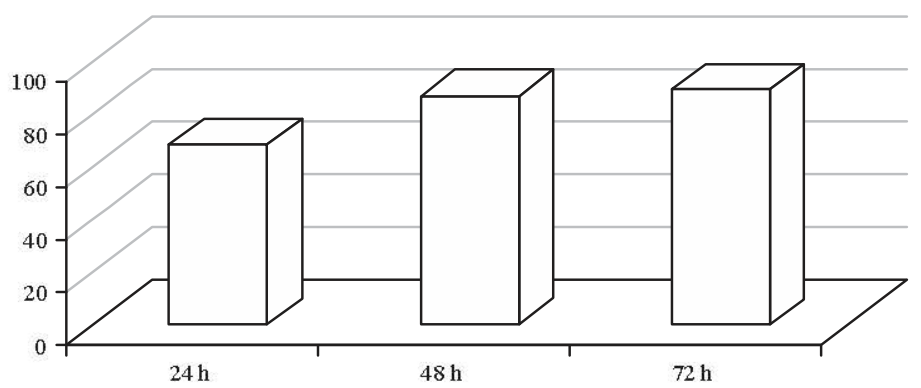

Fig. 2: Removing percentage of $E$. coli under deferent concentration of green alga C. humicola

Table 1: Growth account for $E$. coli under deferent concentration of green alga C. humicol

\begin{tabular}{llll}
\hline $\begin{array}{l}\text { Concentration } \\
\text { (mg L }\end{array}$ & Growth account & & \\
\hdashline & $24 \mathrm{~h}$ & $48 \mathrm{~h}$ & $72 \mathrm{~h}$ \\
\hline Control & $480.0 \pm 11.36^{\text {A** }}$ & $480.0 \pm 10.41^{\mathrm{A*}}$ & $479.3 \pm 9.9^{\text {A* }}$ \\
0.07 & $303.0 \pm 3.33^{\text {A** }}$ & $200.0 \pm 11.55^{\text {c** }}$ & $168.0 \pm 17.50$ \\
0.15 & $303.0 \pm 40.44^{\text {A* }}$ & $177.0 \pm 16.80^{\text {c** }}$ & $133.0 \pm 11.00$ \\
0.31 & $248.0 \pm 21.28^{\text {b* }}$ & $100.0 \pm 1.0$ & $100.0 \pm 5.77$ \\
0.62 & $180.0 \pm 14.43^{\text {b* }}$ & $72.0 \pm 2.3^{\text {d** }}$ & $61.0 \pm 10.51$ \\
1.25 & $99.0 \pm 72$ & $61.0 \pm 2.1^{\text {d** }}$ & $49.0 \pm 6.51$ \\
\hline
\end{tabular}

Small letter*: No significant in the same column, Capital letter: No significant in same row at 0.05 level

Table 2: Removal account for $E$. coli under deferent concentration of green alga C. humicola

\begin{tabular}{|c|c|c|c|}
\hline \multirow{2}{*}{$\begin{array}{l}\text { Concentration } \\
\left(\mathrm{mg} \mathrm{L}^{-1}\right)\end{array}$} & \multicolumn{3}{|c|}{ Removal account } \\
\hline & $24 \mathrm{~h}$ & $48 \mathrm{~h}$ & $72 \mathrm{~h}$ \\
\hline Control & $0.0 \pm 0.0$ & $0.0 \pm 0.0$ & $0.0 \pm 0.0$ \\
\hline 0.07 & $150.0 \pm 13.20^{\mathrm{a} *}$ & $276.0 \pm 19.43^{\mathrm{c*} *}$ & $312.0 \pm 13.0^{\mathrm{f} f \mathrm{k}}$ \\
\hline 0.15 & $180.0 \pm 4.62^{\mathrm{a} a \mathrm{k}}$ & $303.0 \pm 3.51^{\mathrm{cks}}$ & $347.0 \pm 29.6^{f_{* 0}}$ \\
\hline 0.31 & $230.0 \pm 7.51$ & $380.0 \pm 10.44$ & $380.0 \pm 40.7^{\mathrm{f} * \mathrm{k}}$ \\
\hline 0.62 & $300.0 \pm 7.53^{\mathrm{b} * \mathrm{k}}$ & $408.0 \pm 5.29^{\mathrm{cok}}$ & $419.0 \pm 19.0$ \\
\hline 1.25 & $333.0 \pm 9.53^{b *}$ & $419.0 \pm 14.53^{\mathrm{d} * *}$ & $431.0 \pm 2.00$ \\
\hline
\end{tabular}

Table 3: Mortality percent (MP) for E. coli under deferent concentration of green alga C. humicola

\begin{tabular}{|c|c|c|c|}
\hline \multirow[b]{2}{*}{$\begin{array}{l}\text { Concentration } \\
\left(\mathrm{mg} \mathrm{L}^{-1}\right)\end{array}$} & \multicolumn{3}{|c|}{ Mortality percent } \\
\hline & $24 \mathrm{~h}$ & $48 \mathrm{~h}$ & $72 \mathrm{~h}$ \\
\hline Control & $0.0 \pm 0.0$ & $0.0 \pm 0.0$ & $0.00 \pm 0.0$ \\
\hline 0.07 & $31.3 \pm 0.43$ & $58.3 \pm 0.33$ & $65.00 \pm 2.52$ \\
\hline 0.15 & $37.5 \pm 5.01$ & $63.1 \pm 1.13$ & $71.96 \pm 1.28$ \\
\hline 0.31 & $47.9 \pm 0.53$ & $79.1 \pm 0.04$ & $79.17 \pm 0.17$ \\
\hline 0.62 & $62.5 \pm 2.02$ & $85.0 \pm 1.73^{\mathrm{a} \text { a }}$ & $87.30 \pm 0.84^{b t}$ \\
\hline 1.25 & $68.8 \pm 4.79$ & $87.3 \pm 0.29^{\mathrm{a} *}$ & $89.76 \pm 1.76^{b+1}$ \\
\hline
\end{tabular}

While the removing percentage registered 60,80 and $82 \%$ after 24,48 and $72 \mathrm{~h}$. Which refers to increased the removal rate (Fig. 2).

Also the study agrees with Taskin et al. (2010), which indicated the ability of Cladophora extract to reduce the number of $E$. coli bacteria, the reason is due to the secretion of many substances such as Ferpenoids, fatty acids. acids, amino, which have inhibitory effect on bacteria (Xu et al., 2004). And they produce a wide variety of chemically active metabolites in their surroundings, potentially as an aid to protect themselves against the other selling organisms (Rao et al., 2007). These active metabolites also known as biogenic compounds, such as halogenated compounds, alcohols, aldehydes, terpenoids, are produced by several species of marine macro and microalgae and have antibacterial, anti-algal and anti-fungal properties which are effective in the prevention of bio fouling and have other uses in therapeutics (Dahiru and Obidoa, 2007).

The algae extract has an inhibitory effect against the positive and negative bacteria (Gram stain) by inhibiting the Enzyme of phosphatase protein, which plays an important role in the process of inserting substances into the body of the organism Dahiru and Obidoa (2007).

The active substances found in the algae extract have an effect on the positive bacteria of (Gram stain) rather than on the negative bacteria.

As indicated by Ordog et al. (2004). The reason is that the negative bacteria are less sensitive than the active compounds found in positive bacteria of (Gram stain) due to their cell wall structure, which consists of many layers (Abd-Elnaby, 2010). 


\section{REFERENCES}

APHA., 2005. Standard Method for the Examination of Water and Wastewater. 21th Edn., American Public Health Association, Washington, DC, USA.

Abd-Elnaby, H., 2010. Bacteria-algae interactions in Abu-Qir Marine ecosystem and some applied aspects of algal extracts. J. Applied Sci. Res., 6: 345-357.

Beuchat, L.R., 1996. Pathogenic microorganisms associated with fresh produce. J. Food Protect., 59: 204-216.

Cervenka, L., I. Peskova, E. Foltynova, M. Pejchalova, I. Brozkova and J. Vytrasova, 2006. Inhibitory effects of some spice and herb extracts against Arcobacter butzleri, A. cryaerophilus and A. skirrowii. Curr. Microbial., 53: 435-439.

Collee, J.G., A.G. Fraster, B.P. Mamion and A. Simmons, 1996. Mackie and McCartney Practical Medical Microbiology. 14thEdn., Elsevier, New York, USA., ISBN-13: 9788131203934 , Pages: 978.

Dahiru, D. and O. Obidoa, 2007. Pretreatment of albino rats with aqueous leaf extract of Ziziphus mauritiana protects against alcohol-induced liver damage. Trop. J. Pharm. Res., 6: 705-710.

$\mathrm{EU}, 2000$. Directive 2000/60/EC of the European parliament and of the council of 23 October 2000 establishing a framework for the Community action in the field of water policy. Off. J. Eur. Commun. L, 327: 1-72.

Eppley, R.W., W.G. Harrison, S.W. Chisholm and E. Stewart, 1977. Particulate organic-matter in surface waters off Southern-California and its relationship to phytoplankton. J. Mar. Res., 35: 671-696.

Jawad, A.M., 1982. Interaction between cyanobacteria and other micro-organisms. Ph.D. Thesis, University of Liverpool, England.

Katırcioğlu, H., B.S. Akin and T. Atici, 2004. Microalgal toxin (s): Characteristics and importance. Afr. J. Biotechnol., 3: 667-674.

Kumar, R.S., N. Thajuddin and C. Venkateswari, 2010. Antibacterial activity of cyanolichen and symbiotic cyanobacteria against some selected microorganisms. Afr. J. Microbiol. Res., 4: 1408-1411.

Likens, G.E., 2010. Plankton of Inland Waters. 1st Edn., Academic Press, USA., pp: 99-110.

Mahmoudi, N., 2013. Assessing in situ degradation of petroleum hydrocarbons by indigenous microbial communities. Ph.D. Thesis, McMaster University, Hamilton, Canada.
Marina, B., A.I. Noor and E.R. Aweng, 2013. Biodegradation of oily wastewater by pure culture of Bacillus cereus. J. Agric. Biol. Sci., 8: 108-115.

NCERT., 2008. Biology: Textbook for Class XI. 1stEdn., National Council of Education Research and Training, New Delhi, India, Pages: 365.

Ordog, V., W.A. Stirk, R. Lenobel, M. Bancirova and M. Strnad et al., 2004. Screening microalgae for some potentially useful agricultural and pharmaceutical secondary metabolites. J. Applied Phycol., 16: 309-314.

Rao, M., S. Malhotra, T. Fatma and A. Rattan, 2007. Antimycobacterial activity from cyanobacterial extracts and phytochemical screening of methanol extract of Hapalosiphon. Pharm. Biol., 45: 88-93.

SEPA., 2002. A study of bathing waters compliance with EC directive 76/160/EEC: The relationship between exceedance of standards and antecedent rainfall. Scotish Environmental Protection Agency.

Stein, J.R., 1973. Handbook of Phycological Methods, Culture Methods and Growth Measurements. Cambridge University Press, UK., Pages: 448.

Stengel, D.B. and S. Connan, 2015. Marine Algae: A Source of Biomass for Biotechnological Applications. In: Natural Products from Marine Algae: Methods and Protocols, Stengel, D.B. and S. Connan (Eds.). Humana Press, New York, USA., ISBN:978-1-4939-2683-1, pp: 1-37.

Stephan, R. and F. Untermann, 1999. Virulence factors and phenotypical traits of verotoxin-producing Escherichia coli strains isolated from asymptomatic human carriers. J. Clin. Microbiol., 37: 1570-1572.

Taskin, E., M. Ozturk, E. Taskin and O. Kurt, 2007. Antibacterial activities of some marine algae from the Aegean Sea (Turkey). Afr. J. Biotechnol., 6: 2746-2751

Taskin, E., Z. Caki, M. Ozturk and E. Taskin, 2010. Assessment of in vitro antitumoral and antimicrobial activities of marine algae harvested from the eastern Mediterranean sea. Afr. J. Biotechnol., 9: 4272-4277.

Xu, N., X. Fan, X. Yan and C.K. Tseng, 2004. Screening marine algae from China for their antitumor activities. J. Applied Phycol., 16: 451-456.

Yamaguchi, K., H. Nakano, M. Murakami, S. Konosu and O. Nakayama et al., 1987. Lipid composition of a green alga, Botryococcus braunii. Agric. Biol. Chem., 51: 493-498.

Zhao, J., B. Zhang and Y. Zhang, 2008. Chlorophytes of biological soil crusts in Gurbantunggut Desert, Xinjiang Autonomous Region, China. Front. Biol. China, 3: 40-44. 